\title{
Growth, energy storage, and feeding patterns reveal winter mortality risks for juvenile Pacific herring in Prince William Sound, Alaska, USA
}

\author{
Fletcher Sewall ${ }^{1,2, *}$, Brenda Norcross $^{2}$, Johanna Vollenweider ${ }^{1}$, Ron Heintz ${ }^{1}$ \\ ${ }^{1}$ Auke Bay Laboratories, Alaska Fisheries Science Center, NMFS, NOAA, 17109 Point Lena Loop Rd, Juneau, AK 99801, USA \\ ${ }^{2}$ College of Fisheries and Ocean Sciences, University of Alaska Fairbanks, PO Box 757220, Fairbanks, AK 99775, USA
}

\begin{abstract}
First winter survival of juvenile cold temperate fish can be an important recruitment driver. Winter survival may be influenced by size and energy reserves, with larger, fatter individuals less vulnerable to predation and starvation. However, limited information regarding relationships among size, growth, and energy reserves often hampers understanding recruitment processes for economically and ecologically important marine species. To better understand winter mortality risks, we examined growth and lipid storage patterns in young-of-the-year (YOY) Pacific herring Clupea pallasii in Prince William Sound, Alaska, USA, near the onset (November) and end (March) of 7 winters during 2009-2016 that occurred before and during the North Pacific marine heat wave. Herring length in November determined energy allocation, with a shift from proteinbased growth to lipid storage occurring at $\sim 76 \mathrm{~mm}$ fork length. We suggest that size-selective predation pressure causes small herring below this size to favor growth over storing fat. Low March lipid stores apparently compelled herring to avoid starvation by foraging, behavior that could increase predation risk especially for small herring. Larger herring ate more high-quality euphausiid prey than did small herring during November, reinforcing the advantages of large size. Herring lipid stores were highest in the coldest study year, rather than the year with the best diets, presumably due to low temperature slowing metabolic rates. Our findings suggest overwinter survival models could be improved with unbiased estimates of late autumn YOY herring size and energy distributions, seasonal temperature measurements, estimates of food consumption, and knowledge of local predator densities.
\end{abstract}

KEY WORDS: Bioenergetics · Clupea pallasii $\cdot$ Pacific herring $\cdot$ Early life history $\cdot$ Growth $\cdot$ Lipid · Size-selective mortality · Prince William Sound

\section{INTRODUCTION}

Survival of juvenile marine fishes prior to recruitment to adult stocks is determined via poorly understood processes that - for many stocks of small pelagic fish — result in weak relationships between stock size and annual recruitment (Zheng 1996). Uncertainty in the stock-recruitment relationship for high-latitude fishes can be driven by variable young-of-theyear (YOY) winter mortality (Hurst 2007). Develop-

${ }^{*}$ Corresponding author: fletcher.sewall@noaa.gov ing mechanistic models relating winter survival to specific fish traits and environmental factors may improve the ability to predict recruitment (Heintz et al. 2013). However, mortality processes for fish in highlatitude marine environments in winter are generally not well-studied (Hurst 2007).

For pre-recruit fish, chances of survival may increase for individuals that grow rapidly to large size (Anderson 1988, Miller et al. 1988). Greater body mass and length generally improve survival of juvenile fish by restricted. Authors and original publication must be credited. 
reducing their vulnerability to both starvation and predation (Sogard 1997). For example, size is a key predictor in models of juvenile Pacific salmon Oncorhynchus spp. survival, for which failure to reach a minimum critical size by autumn results in higher winter mortality (Beamish \& Mahnken 2001, Moss et al. 2005). Size-dependent winter mortality among salmon has been linked to size-related differences in stored energy levels (Beamish \& Mahnken 2001, Farley et al. 2011). Stored energy levels are thus often used as an alternative indicator of mortality risk. Winter mortality risk in wild fish populations is inferred to be high if they approach minimum levels of lipid or energy necessary for survival in laboratory studies (Paul \& Paul 1998, Sogard \& Olla 2000). Some models relating winter survival to energy reserves rely solely on laboratory-derived energy loss rates, the number of days spent fasting, and the minimum energy density required for survival (Paul \& Paul 1998, Patrick 2000). Yet, size or energy data alone may not provide the best survival estimates. For example, survival of juvenile walleye pollock Gadus chalcogrammus to age- 1 is better predicted when size and energy data are combined (Heintz et al. 2013).

Attaining large size and energy stores for winter survival may be promoted by late autumn growth and food availability. Late season growth has been associated with YOY survival for northern freshwater species (Huss et al. 2008, Post \& Parkinson 2001). A fish that is able to eat and sustain growth at the onset of winter is unlikely to be consuming its stored energy. As juvenile fish grow, their capacity for storing energy increases more rapidly than their metabolic costs (e.g. for walleye pollock; Heintz \& Vollenweider 2010). Thus, fish that are eating well and growing in late autumn should be less vulnerable to starvation during winter, when zooplankton abundance typically declines (Foy \& Norcross 2001, McKinstry \& Campbell 2018).

Prey availability strongly influences the response of juvenile fish growth to temperature. When food is more abundant, growth rate increases rapidly with temperature and peaks at a higher temperature (Beauchamp et al. 2007). However, growth may be inhibited when temperature exceeds the optimal range for a given species (Laurel et al. 2016). High temperatures can also be associated with lower abundance of zooplankton prey in autumn and winter (Foy \& Norcross 2001).

Zooplankton scarcity in winter likely increases the predation risk associated with visual foraging (Scheuerell \& Schindler 2003), especially for smaller fish (Sogard \& Olla 1997). When food is limited, fish appear to increase their searching activity (Sogard \& Olla 1996). Small fish use their energy stores at higher rates than larger fish (Schultz \& Conover 1999) and are consequently more reliant on foraging to survive winter (Heintz \& Vollenweider 2010). Greater predation vulnerability of small fish is thus likely a major driver of size-dependent mortality in winter (Sogard 1997).

Pacific herring Clupea pallasii (hereafter herring) serves as an instructive model organism for investigating winter mortality mechanisms in a small pelagic fish species due to its life history, ecology, behavior, and social value. Herring in Prince William Sound (PWS), Alaska supported a commercial fishery before the population crashed in the early 1990s (Thomas \& Thorne 2003, Hulson et al. 2008). Additionally, it is an ecologically important forage fish prey for piscivorous fish, seabirds, and marine mammals in part due to its schooling behavior and high lipid stores (Iverson et al. 1997, Thomas \& Thorne 2001). Storing lipids depends on seasonally variable zooplankton prey that becomes scarce in winter (Foy \& Norcross 2001). Consequently, winter feeding and growth for YOY herring are limited and mortality risk is high. Mortality of YOY herring overwintering in dense schools nearshore exceeds that of older herring offshore, and varies among years and bays in PWS (Stokesbury et al. 2002). Model mortality estimates can be as high as $95 \%$, suggesting that first year winter mortality is a primary driver of year-class strength (Norcross \& Brown 2001, Norcross et al. 2001). Thus, understanding the mechanisms of YOY herring winter mortality would improve predictive models of survival and ultimately recruitment.

The goal of this study was to identify juvenile herring traits and environmental factors useful for understanding mechanisms driving first-winter herring survival. To this end, we investigated relationships among size, growth, energy storage, and diet for YOY herring collected from PWS at the beginning and end of 7 winters. Specifically, we sought to determine how protein-based growth and lipid stores relate to YOY herring size at the beginning and end of winter, and how lipid stores influence foraging at the end of winter. We also examined how herring lipid stores at the beginning of winter differed by location and year, and if this could be attributed to differences in diets. This information allowed us to assess the evidence for a critical size that YOY herring must achieve for winter survival and thereby provide insight into mortality processes for a highlatitude small pelagic fish. 


\section{MATERIALS AND METHODS}

\subsection{Field sampling}

Juvenile herring were collected from multiple sites in Prince William Sound, Alaska (Fig. 1) during November and March across 7 winters (November 2009 through March 2016), to investigate spatial and interannual variability in growth, energy storage, and diets. Sampling effort (Table S1 in the Supplement at www.int-res.com/articles/suppl/m623p195_ supp.pdf) focused on Eaglek Bay, Lower Herring Bay, Simpson Bay, Whale Bay, and Zaikof Bay, due to their coverage across regions of PWS and for continuity with previous herring research (Norcross et al. 2001), while additional bays (Port Fidalgo, Port Gravina, and Windy Bay) were sampled opportunistically. Collection gear included cast nets $(4.8 \mathrm{~mm}$, $6.4 \mathrm{~mm}$, and $9.5 \mathrm{~mm}$ square mesh), single- and variable-mesh gillnets $(9.5,12.7$, and $19.1 \mathrm{~mm}$ square mesh through 2012; 6.4, 7.9, and $9.5 \mathrm{~mm}$ square mesh after 2012), and mid-water trawls $(38 \mathrm{~mm}$ square mesh at opening decreasing to $12 \mathrm{~mm}$ at codend). Collected herring were randomly subsampled, frozen, and transported by air to the Alaska Fisheries Science Center's Auke Bay Laboratories (Juneau, AK), for measurements of fork length (FL, to nearest $1 \mathrm{~mm}$ ) and wet weight (to nearest $0.001 \mathrm{~g}$ ) along with chemical analysis. Growth and energy

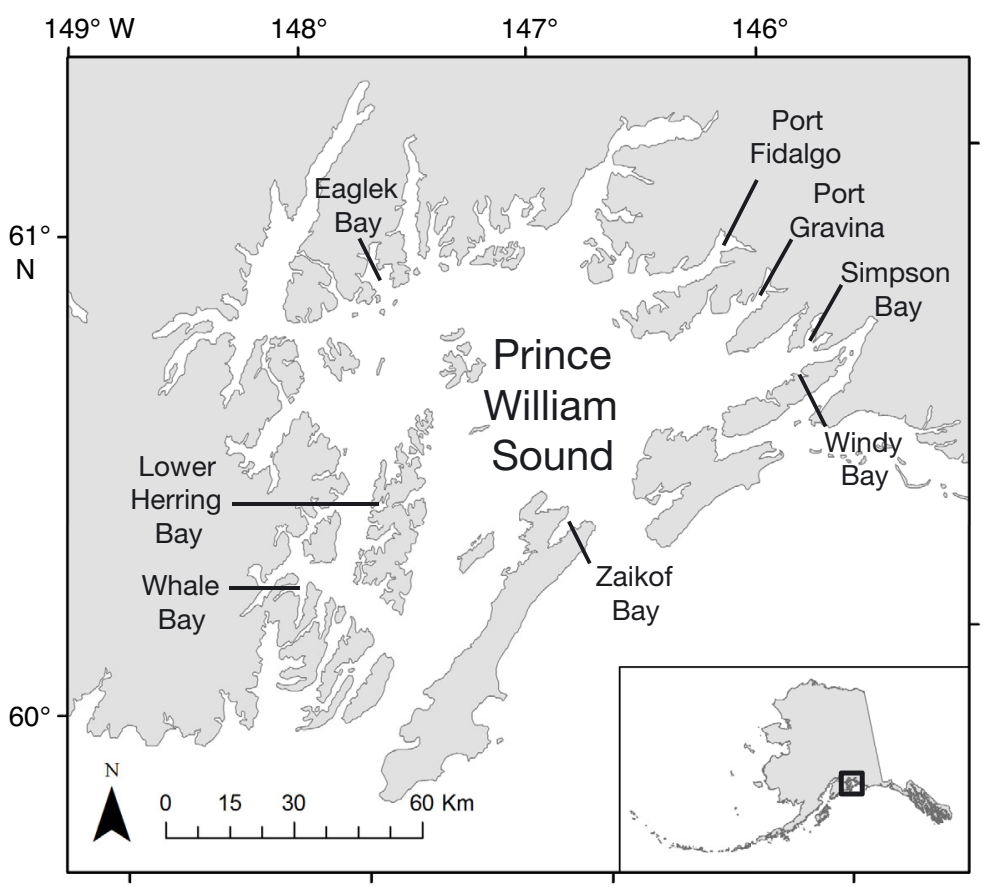

Fig. 1. Study area indicating primary collection sites for young-of-the-year Pacific herring stores were typically measured on a target sample size of 20 individuals per site within a bay (Table $\mathrm{S} 2)$, chosen in 5-mm size bins to proportionally represent the length-frequency distributions of the field-collection subsamples. Catches were generally smaller in March than the preceding November. Sample sizes for analysis across PWS ranged from 139 for November 2013 to 28 for March 2016.

\subsection{Growth}

The recent growth of individual herring was assessed using RNA/DNA ratios. Higher RNA/DNA indicates greater protein synthesis rates over the preceding few days (Buckley 1984, Buckley et al. 1999). The RNA and DNA contents of $10-15 \mathrm{mg}$ plugs of dorsal white muscle tissue representing less than $1 \%$ of fish body mass were determined with a fluorometric dye-binding assay using the methodology of Caldarone et al. (2001) as modified by Sreenivasan (2011). Muscle tissues were sonicated in buffered detergent, sequentially treated with fluorescing dye, RNase, and DNase enzymes, and fluorescence was read by spectrophotometer at each step. Fluorescence readings were calibrated according to the RNA/DNA ratios in known quantities of standard materials, consisting of calf liver $18 \mathrm{~S}+28 \mathrm{~S}$ ribosomal RNA and calf thymus DNA (Sigma), that were run with each batch of 20 samples. Sample RNA/DNA ratios across multiple processing batches were standardized to an average standard slope ratio of 3.84 to ensure comparability among batches and to facilitate comparisons with other studies (Caldarone et al. 2006). Method blanks were processed concurrently with samples to check for contaminants introduced at any step in the procedure.

\subsection{Energy storage}

The lipid content of herring was used as a measure of stored energy. Prior to lipid analysis of herring, stomachs were excised, stomach contents removed and stored individually for diet analysis, and stomachs returned to carcasses. Following removal of muscle plugs and stomach contents, individual herring were homogenized with mortar and pestle to minimize tissue loss. 
Homogenates were analyzed for lipid mass as a percentage of wet tissue mass (\% lipid) following procedures described in Vollenweider et al. (2011b). Briefly, lipid extraction was performed following a modified Folch method (Folch et al. 1957) using a Dionex 200 Accelerated Solvent Extractor, followed by drying and weighing lipid extracts. NIST reference materials were used for quality control to verify lipid analysis. Each sample batch was also processed concurrently with in-house reference materials to check accuracy, a sample replicate to check precision, and a method blank to check for contaminants.

The minimum lipid level needed for survival was estimated using data from a previous laboratory study of captive juvenile herring (Vollenweider et al. 2011a). For that study, YOY herring were collected in Puget Sound, WA, held at 3 temperatures in replicated tanks, and fed until a 10-wk winter fasting period. Fish that died while fasting were sampled $(n=45)$ for lipid analysis. Log-transformed lipid data were pooled from starvation mortalities across treatment groups to establish the average survival threshold level of lipid cited in the present study.

\subsection{Feeding and diet}

To assess influences of diet mass and composition on herring growth and energy stores, and as an indicator of foraging activity, stomach contents were weighed throughout the study period. For the last 5 winters of the study, November 2011 through March 2016, individual prey items were then enumerated and identified to the lowest taxon practical. Due to degradation from digestion and handling, total mass of prey by taxon was estimated by multiplying counts of individuals for each taxon by values for their undigested mass from literature (Coyle et al. 1990, Foy \& Norcross 1999). Thus all prey of a given taxon were assumed to have the same mass, given the impracticality of accurately measuring all prey items.

\subsection{Statistical analysis}

\subsubsection{Size-based trade-offs between growth} and energy storage

To evaluate the relationship between YOY herring growth and energy storage, RNA/DNA and \% lipid data pooled across years were fit to length for November and March using piecewise linear regressions (Muggeo 2003). Relationships to size were reported on a length basis rather than mass basis because \% lipid is a mass-based index and therefore $\%$ lipid and mass would not be independent measures. RNA/DNA and lipid data were transformed (natural log and square root, respectively) to meet regression assumptions of normally distributed residuals and equal variances. A piecewise regression approach was used because we expected the energy allocation strategy could shift at a fixed length for juvenile herring, as has been observed for other juvenile fishes in seasonal environments (Post \& Parkinson 2001, Stallings et al. 2010). In addition, exploratory analysis of November data using generalized additive models (GAMs; Wood 2006) suggested that the slopes of the relationships between RNA/DNA or \% lipid and length were not linear and changed abruptly at intermediate lengths. The RNA/DNA-length relationship had up to 2 plausible breakpoints: one at which RNA/ DNA decreased rapidly with length, and a second at which RNA/DNA reached a minimum metabolic threshold and remained constant with length. The lipid-length relationship had 1 plausible breakpoint at which lipid increased rapidly with length, with no upper limit observed. Given that the relationships of RNA/DNA and \% lipid to length could follow piecewise linear patterns, statistical software (R package 'Segmented'; Muggeo 2014) employing least-squares regression was used to identify the line breakpoints where the relationships changed. To compare use of plausible alternative models, piecewise (1 or 2 breakpoints for RNA/DNA, 1 breakpoint for lipid), simple linear, quadratic, and GAM (limited to $\leq 4$ knots) candidate models were ranked using Akaike's information criterion (AIC):

$$
\mathrm{AIC}=-2 \ln (L)+2 K
$$

where $L$ is the likelihood, and $K$ is the number of parameters in the model. The model with the lowest AIC score was deemed the best; models scoring $0-2$ points higher had 'substantial support,' those scoring 4-7 higher had 'considerably less support,' and those scoring $>10$ higher had 'essentially no support' (Burnham \& Anderson 2004).

\subsubsection{Growth and energy storage across years and bays}

To assess the influence of year and location on growth and energy stores, a 2-way ANOVA was performed using the best regression model residuals for RNA/DNA and \% lipid as the response variables. 
Residuals from the best regression models were used to remove the effects of herring size. Size bias in the herring sampling gear prohibited direct comparisons of growth or energy storage among years and bays, with cast nets capturing smaller fish during November (mean FL $\pm \mathrm{SE}: 72.8 \pm 0.8 \mathrm{~mm}, \mathrm{n}=290$ ) than trawls $(85.4 \pm 1.1 \mathrm{~mm}, \mathrm{n}=145)$ or gillnets $(88.7 \pm 0.7 \mathrm{~mm}$, $\mathrm{n}=309$ ) (Fig. S1). ANOVA was performed only using the 5 primary bays with data from November and March for at least 2 of the 7 years (Table S2), and year-bay interactions were not tested due to missing data. Post-hoc Tukey pairwise comparisons were used to identify specific years and bays that differed.

To investigate the role of temperature in driving yearly differences in growth or energy stores, water temperature data was obtained from the NOAA Cordova tide station $\left(60^{\circ} 33.5^{\prime} \mathrm{N}, 145^{\circ} 45.3^{\prime} \mathrm{W}\right)$. Annual mean temperatures were obtained by averaging hourly, daily, and then monthly values. Mean annual residuals from lipid and RNA:DNA piecewise regressions were fit to annual average water temperatures in simple linear regression models.

\subsubsection{Feeding and diet}

To investigate diet as a driver of differences in herring growth and energy stores, we compared YOY herring diets among years and bays using several metrics. Stomach fullness, expressed as stomach contents mass as a percentage of herring body mass, was used as an indicator of feeding success. To assess whether depletion of energy stores influenced feeding, stomach fullness as a function of lipid level in November versus March was compared using rankbased robust regression employing a Wald test and reduction in dispersion test (Kloke \& McKean 2012) using the $\mathrm{R}$ 'Rfit' rank-based estimation package (Kloke \& McKean 2016). Note that for a given fish, percent stomach fullness and percent lipid are independent measures of stomach contents mass and lipid mass, respectively, normalized to body mass. Frequency of occurrence of prey by taxa during November was calculated to assess differences in prey selection across years. To simplify analysis, prey were aggregated into groups of large copepod species, small copepod species, euphausiids, and other taxa. Large versus small copepods were categorized based on adult body length greater or less than $2.5 \mathrm{~mm}$, following the convention of Foy \& Norcross (1999). Euphausiids included primarily adults and few furcilia. To evaluate the relative importance of different prey, the average contribution by mass for each prey group
(\%) was determined for all samples pooled at the level being compared (year or bay). Diet composition differences by year, bay, and herring length were assessed by non-parametric permutational multivariate ANOVA (PERMANOVA) based on Bray-Curtis dissimilarities in taxa proportions by mass (Anderson 2001), using the R 'Vegan' community ecology package (Oksanen et al. 2018). Opportunistically sampled bays such as Port Fidalgo were excluded from that analysis due to limited years of data. Variation in the probability of eating individual prey taxa as a function of herring length was evaluated using logistic regression on prey presence/absence data. Simpson Bay and opportunistic bays were excluded from that analysis due to absence of euphausiids. Diet types were assigned according to the category of prey that made up at least $50 \%$ of the diet mass they consumed. High variability and skew in the diet data required log transformation and use of non-parametric Mann-Whitney tests, and Welch's ANOVA (Welch 1951, Day \& Quinn 1989) using weighted least squares to compare years and bays due to unequal variances. Games-Howell pairwise comparisons (Games \& Howell 1976, Day \& Quinn 1989) were used to identify specific years and bays that differed.

\section{RESULTS}

\subsection{Size-based trade-offs between growth and energy storage}

Energy allocation to protein-based growth versus lipid storage varied with YOY herring length. For November, the relationship of RNA/DNA to length was best described by a piecewise regression model with 2 breakpoints (Fig. 2; Table S3 in the Supplement) that identified lengths where the relationship shifted. Herring smaller than $74 \mathrm{~mm}$ FL (95\% CI: 70-78 mm) in November typically had the highest RNA/DNA, while RNA/DNA decreased rapidly with length for individuals larger than $74 \mathrm{~mm}$ FL (piecewise regression, $\left.\mathrm{R}^{2}=0.36, \mathrm{p}<0.001\right)$. RNA/DNA for herring larger than $85 \mathrm{~mm}$ FL (95\% CI: 82-88 mm) approached a minimum level for routine metabolism and no growth, as previously determined in herring starved under laboratory conditions (RNA/DNA ratio $\sim 4-5$; Sreenivasan 2011). In contrast, YOY herring lipid content for November increased with body size. Herring larger than $76 \mathrm{~mm}$ FL (95\% CI: 65-87 mm) stored lipid at a higher rate than smaller herring. Percent lipid and FL were weakly related (piecewise regression, adj. $\mathrm{R}^{2}=0.15, \mathrm{p}<0.001$ ). 


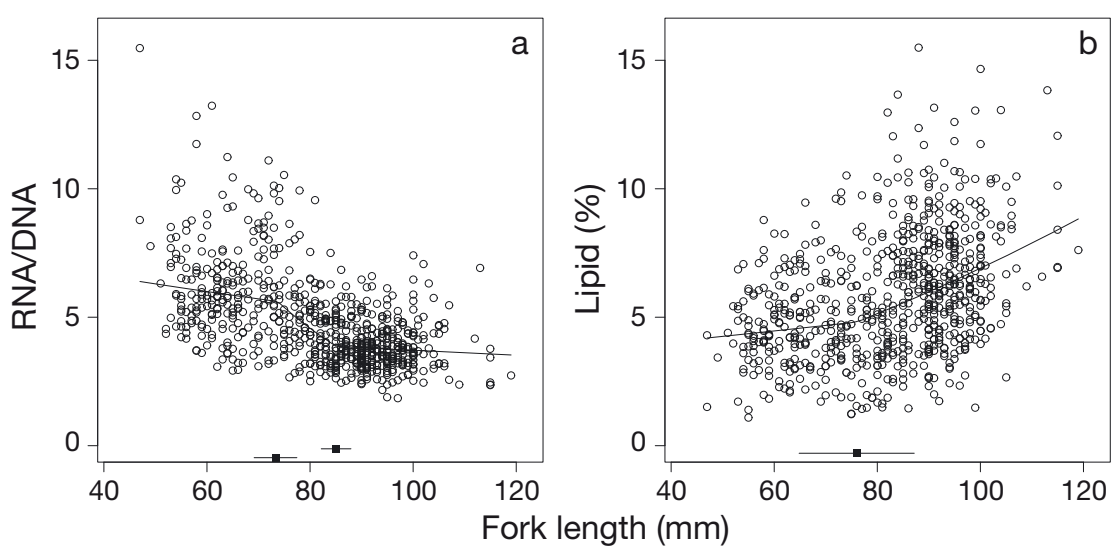

Fig. 2. (a) RNA/DNA ( $\mathrm{n}=745)$ and (b) lipid content $(\%$ wet tissue mass) $(\mathrm{n}=734)$ as a function of fork length, for young-of-the-year herring collected in Prince tiated and squared) predicted values from the piecewise regression model fits to log- and square-root transformed data (bars at bottom: break-points and $95 \%$ CIs) William Sound, AK, in November 2009-2015. Lines : back-transformed (exponen-

and bays in PWS. Year and bay significantly influenced November growth (2-way ANOVA, $\mathrm{R}^{2}=37.1 \%$; $F_{\text {Year 6,639 }}=39.58, \mathrm{p}<0.001 ; F_{\text {Bay } 4,639}=$ 26.65, p $<0.001$ ) and lipid levels (2-way ANOVA, R ${ }^{2}=17.8 \% ; F_{\text {Year } 6,628}$ $=17.65, \mathrm{p}<0.001 ; F_{\text {Bay } 4,628}=5.63, \mathrm{p}<$ 0.001). Herring in 2012 had the highest RNA/DNA ratio (Table 1) and \% lipid (Table 2) over the 7-yr period studied. The 2012 cohort continued to have high lipid levels in March 2013 (2-way ANOVA, R ${ }^{2}=$ $23.2 \% ; F_{\text {Year } 6,373}=16.17, \mathrm{p}<0.001$; $F_{\text {Bay } 4,373}=1.13, \mathrm{p}=0.341$; Table 3 ). The 2012 cohort experienced the lowest annual average water temperature of the study period (Fig. 4), suggesting that cooler temperature
For March, relationships of RNA/DNA and $\%$ lipid to length were similar to those for November, with RNA/DNA decreasing with size and lipid increasing with size (Fig. 3), though the best-fitting model forms differed from November (Table S4). The inverse linear relationship between RNA/DNA and FL was weak but statistically significant $\left(\mathrm{R}^{2}=\right.$ $0.21, \mathrm{p}<0.001, \mathrm{n}=446$ ), and showed no evidence of nonlinearity. RNA/DNA values were generally slightly higher in March than November. Lipid levels were generally lower in March than in November, with especially large decreases in \% lipid among herring larger than the November lipid accumulation breakpoint (>76 mm FL). The piecewise model differed negligibly from the best-scoring quadratic model, so it was used to identify the breakpoint at which lipid increased with length. Percent lipid was uniformly low across lengths for herring smaller than $89 \mathrm{~mm}$ FL in March, while lipid levels for larger herring were variable and increased with length, resulting in a significant but weak overall relationship to length (piecewise regression, $\mathrm{R}^{2}=0.08, \mathrm{p}<$ $0.001, \mathrm{n}=461$ ).

\subsection{Growth and energy storage across years and bays}

Growth and condition of YOY herring before winter varied across years promoted YOY herring condition and growth. However, given the short time series, the effects of water temperature on RNA/DNA $(F=3.09, \mathrm{p}=$ $0.139)$ and lipid $(F=2.85, \mathrm{p}=0.152)$ were not statistically significant, and the apparent relationships were largely driven by the low 2012 temperature.

The lipid stores and growth of juvenile herring in November varied widely among bays across years, such that no specific bay consistently produced herring in the best condition (Fig. S2). Simpson Bay herring tended to be below average in growth (Table S5) and lipid (Table S6) across years, while Whale Bay herring tended to be above average across years.

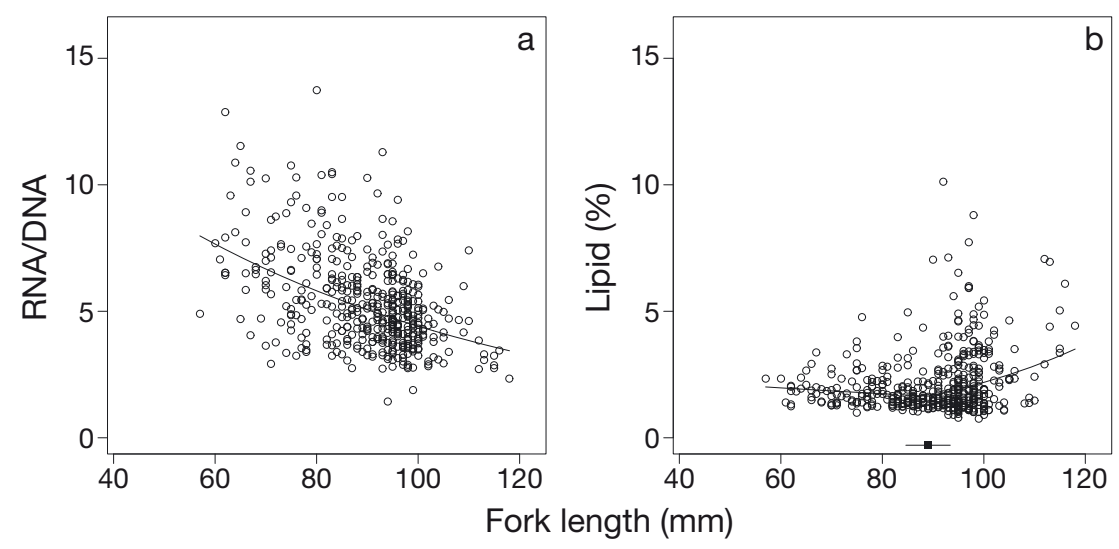

Fig. 3. (a) RNA/DNA ( $\mathrm{n}=446$ ) and (b) lipid content (\% wet tissue mass) ( $\mathrm{n}=$ 461) as a function of fork length, for young-of-the-year herring collected in Prince William Sound, AK, in March 2010-2016. Lines: back-transformed (exponentiated) predicted values from the linear and piecewise regression model fits to log-transformed data, respectively (bar at bottom: breakpoint and $95 \% \mathrm{CI}$ ) 
Table 1. Tukey pairwise comparisons of residuals from piecewise regression of log-transformed RNA/DNA versus fork length for young-of-the-year herring collected in Prince William Sound, AK, in November 2009-2015. Differing superscript letters indicate significant differences between years

\begin{tabular}{|ccc|}
\hline Year & $\mathrm{n}$ & Mean \\
\hline 2012 & 80 & $0.324^{\mathrm{a}}$ \\
2009 & 59 & $0.097^{\mathrm{b}}$ \\
2010 & 125 & $0.038^{\mathrm{b}, \mathrm{c}}$ \\
2015 & 77 & $-0.019^{\mathrm{c}, \mathrm{d}}$ \\
2013 & 104 & $-0.041^{\mathrm{c}, \mathrm{d}}$ \\
2011 & 106 & $-0.046^{\mathrm{d}}$ \\
2014 & 99 & $-0.112^{\mathrm{d}}$ \\
\hline
\end{tabular}

Table 2. As in Table 1, for square-root transformed \% lipid versus fork length for young-of-the-year herring collected in Prince William Sound, AK, in November 2009-2015

\begin{tabular}{|ccc|}
\hline Year & $\mathrm{n}$ & Mean \\
\hline 2012 & 80 & $0.333^{\mathrm{a}}$ \\
2014 & 99 & $0.084^{\mathrm{b}}$ \\
2013 & 103 & $0.052^{\mathrm{b}, \mathrm{c}}$ \\
2011 & 106 & $-0.023^{\mathrm{b}, \mathrm{c}, \mathrm{d}}$ \\
2009 & 77 & $-0.119^{\mathrm{c}, \mathrm{d}, \mathrm{e}}$ \\
2010 & 95 & $-0.157^{\mathrm{d}, \mathrm{e}}$ \\
2015 & 79 & $-0.277^{\mathrm{e}}$ \\
\hline
\end{tabular}

Table 3. As in Table 1, for log-transformed \% lipid versus fork length for young-of-the-year herring collected in Prince William Sound, AK, in March 2010-2016

\begin{tabular}{|ccc|}
\hline Year & $\mathrm{n}$ & Mean \\
\hline 2013 & 20 & $0.795^{\mathrm{a}}$ \\
2014 & 78 & $0.132^{\mathrm{b}}$ \\
2010 & 97 & $-0.022^{\mathrm{b}, \mathrm{c}}$ \\
2015 & 64 & $-0.119^{\mathrm{c}}$ \\
2011 & 60 & $-0.122^{\mathrm{c}}$ \\
2016 & 27 & $-0.175^{\mathrm{c}}$ \\
2012 & 38 & $-0.216^{\mathrm{c}}$ \\
\hline
\end{tabular}

\subsection{Feeding and diet}

Herring nearing exhaustion of their stored fat by late winter were compelled to feed (Fig. 5). Herring stomach fullness was inversely related to lipid level with November and March pooled (Table 4). However, a model with separate slopes by month performed significantly better (reduction in dispersion test, $F=5.5, \mathrm{p}=0.004)$. Using the 2-slope model, comparison of intercepts and slopes showed that stomach fullness for March was higher initially and declined more rapidly with lipid level than for November, indicating a stronger effect and greater need to

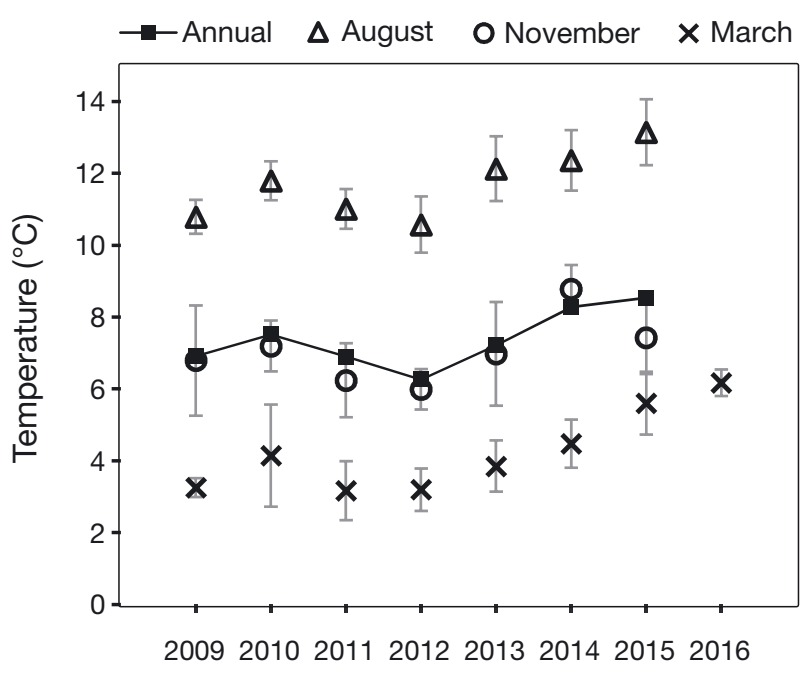

Fig. 4. March, August, November, and annual mean water temperatures $\left({ }^{\circ} \mathrm{C}\right)$ in Prince William Sound, AK, in 20092016, as measured at NOAA Cordova tide station, $\sim 2 \mathrm{~m}$ below mean lower low water. Error bars for monthly means are standard deviations of daily means. Annual means are point estimates. November means are partially obscured by annual means. (Data downloaded 8 Aug 2016 from https:// tidesandcurrents.noaa.gov/stationhome.html?id=9454050)

feed during March. Though herring approaching the minimum survival threshold lipid level of $1.28 \pm 0.10 \%$ tended to be small, and stomach fullness was negatively related to herring length (Table S7), feeding in March also occurred among large herring (Fig. S3).

Juvenile herring in November 2011 generally ate more than during other years, as shown by higher stomach content mass relative to body mass (Fig. S4), though log-transformed stomach fullness values in 2011 did not statistically differ from 2010 and 2012 (Table S8). Diet composition differed by year, bay, and herring length, in order of effect size, though the effects of each were only moderate (Table 5). Relative to other years, diets in 2011 showed a high proportion by mass and frequency of occurrence of euphausiids (Fig. S5), an especially energy-rich prey item (Foy \& Norcross 1999). Euphausiids did not exceed $2 \%$ occurrence in PWS herring stomachs for any of the other 4 years examined.

Across years, the probability of eating euphausiids increased with herring length (logistic regression, $\mathrm{p}<0.001)$, and the relationship was evident in bays with high proportions of euphausiids eaten (e.g. Whale Bay; Fig. 6). Considering only herring larger than 76 mm FL, representing those large enough to store more lipids and eat euphausiids, diets that consisted of primarily euphausiids ( $>50 \%$ by mass) were associated with the highest RNA/DNA (Welch's ANOVA, $\left.\mathrm{R}^{2}=5.00 \%, F_{5,359}=3.54, \mathrm{p}=0.010\right)$ and \% lipid re- 


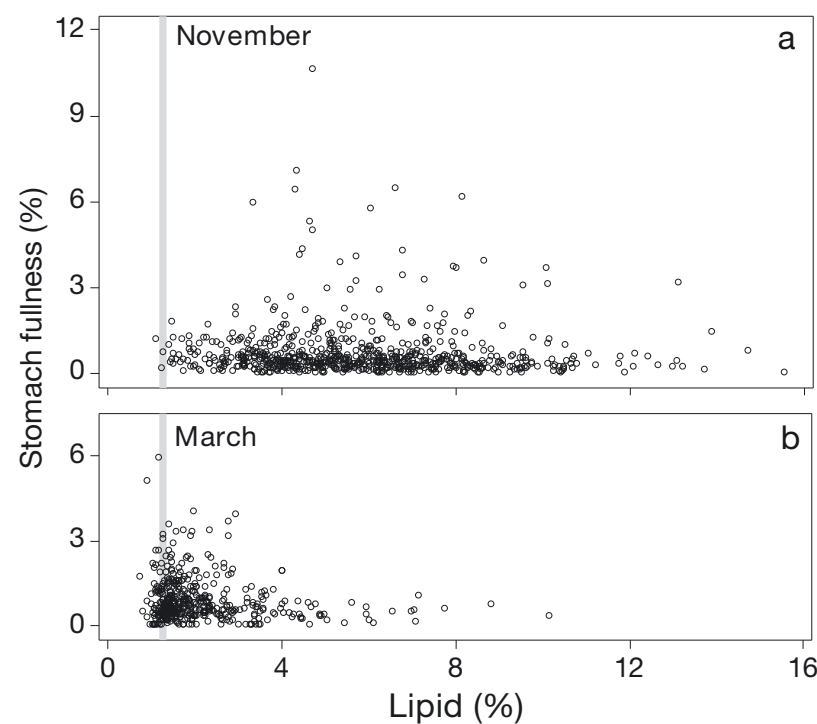

Fig. 5. Stomach fullness (stomach contents mass as \% of body mass) versus lipid content (\% wet tissue mass) for young-ofthe-year herring collected in Prince William Sound, AK, in (a) November 2009-2015 ( $\mathrm{n}=710$ ) and (b) March 2010-2016 ( $\mathrm{n}=444)$. Gray line: survival threshold level of lipid (1.28 \pm $0.10 \%$ ) under laboratory conditions

Table 4. Results from rank-based robust regressions of stomach fullness as a function of lipid content for November and March combined (one-slope model) and considered separately (2-slope model), for young-of-the-year herring collected in Prince William Sound, AK, in November 2009-2015 ( $\mathrm{n}=710)$ and March 2010-2016 ( $\mathrm{n}=444)$

\begin{tabular}{|lrc|}
\hline One-slope model: & Estimate $\pm \mathrm{SE}$ & $\mathrm{p}$ \\
\hline $\begin{array}{l}\text { Overall intercept } \\
\text { Overall slope }\end{array}$ & $0.622 \pm 0.022$ & $<0.001$ \\
Overall Wald Test: $63.3, \mathrm{p}<0.001, \mathrm{R}^{2}=0.053$ & \\
& & \\
Two-slope model: & Estimate $\pm \mathrm{SE}$ & $\mathrm{p}$ \\
\hline Mar intercept & $0.673 \pm 0.034$ & $<0.001$ \\
Nov intercept & $0.548 \pm 0.035$ & $<0.001$ \\
Mar slope & $-0.034 \pm 0.012$ & 0.005 \\
Nov slope & $-0.018 \pm 0.005$ & $<0.001$ \\
Overall Wald Test: $557.9, \mathrm{p}<0.001, \mathrm{R}^{2}=0.063$ & \\
\hline
\end{tabular}

Table 5. Results from PERMANOVA test of differences in diet composition (proportions by mass) by year, bay, and herring length, for young-of-the-year herring with non-empty stomachs collected in Prince William Sound, AK, in November 2011-2015 $(n=284)$

\begin{tabular}{|lccc|}
\hline & $\mathrm{R}^{2}$ & $F$ & $\mathrm{p}$ \\
\hline Year & 0.087 & 7.54 & $<0.001$ \\
Bay & 0.070 & 4.85 & $<0.001$ \\
Length & 0.045 & 15.47 & $<0.001$ \\
Residual & 0.792 & & \\
\hline
\end{tabular}

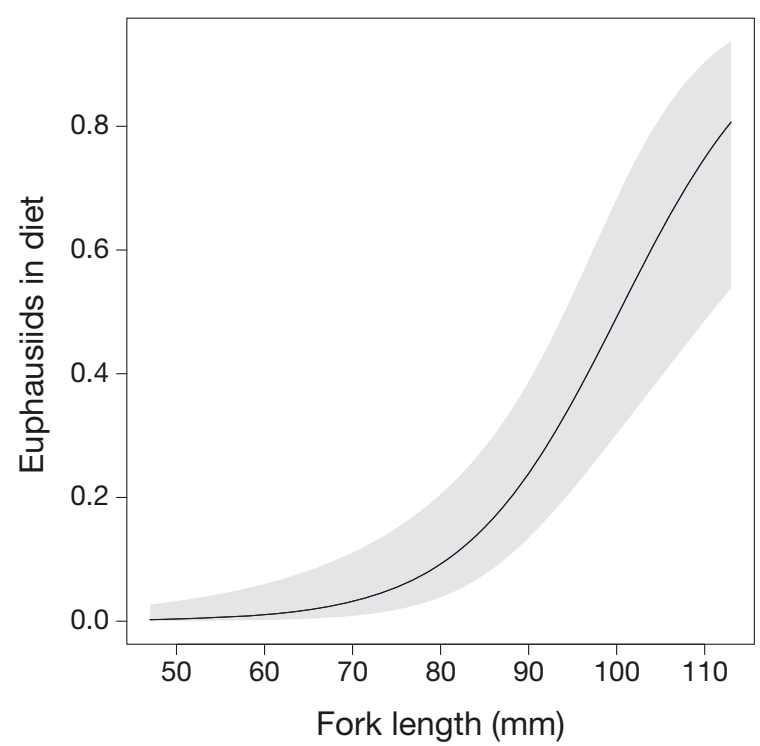

Fig. 6. Probability of eating euphausiids (95\% confidence band) as a function of herring fork length, for young-of-theyear herring with non-empty stomachs collected in Whale

Bay, Prince William Sound, AK, in November 2011-2015

siduals (Welch's ANOVA, $\mathrm{R}^{2}=0.64 \%, F_{5,359}=0.52, \mathrm{p}=$ $0.757)$, although the lipid differences were not significant. Variation in euphausiid consumption among bays in 2011, the only year with significant euphausiids in diets, may have contributed to differences in herring condition. In 2011, among herring larger than $76 \mathrm{~mm} \mathrm{FL}$, those caught in Whale Bay ate the most euphausiids (Fig. S6) and had higher RNA/ DNA and\% lipid than other bays (Fig. S7). Across years however, no bay showed consistently high stomach fullness (Fig. S8).

\section{DISCUSSION}

\subsection{Size- and energy-dependent mortality risks}

YOY herring apparently need to reach a critical size threshold before they begin storing fat for winter. The observed shift from growth at small sizes to energy storage at larger sizes indicates that body size determines the energy allocation strategy of YOY herring near the onset of winter. The shift from growth to energy storage likely reflects tradeoffs in sizedependent winter mortality risks by predation versus starvation. Herring that fail to exceed a critical size by November may continue to allocate energy to growth in an attempt to reduce risk of predation by Pacific cod Gadus macrocephalus, walleye pollock and 
other groundfish (Bishop \& Powers 2013). Groundfish predation declines sharply for YOY herring larger than 75-80 mm FL (Bishop et al. 2017). Because that is smaller than the typical (mean, median, or mode) size of herring captured for this study, it suggests that small YOY herring may be eaten disproportionately to their occurrence in the population, though gear selectivity prohibits definitive size comparison. Predation risk may be reduced for larger juvenile herring due to their increased swimming ability (Christensen 1996) or size relative to the gape size of predators (Scharf et al. 2000). With lower predation risk, larger herring may benefit from a shift in strategy from growth to storing fat for winter use.

Depletion of winter fat stores may compel herring to feed and to risk predation to avoid starvation. Lipid stores during November were generally low among small herring, indicating they started winter with high starvation risk. By late winter in March, small, lean herring tended to have fuller stomachs than larger, fatter herring, suggesting that small herring rely on winter feeding to survive. In contrast, large herring, which generally had high lipid stores at the onset of winter in November, and low stomach fullness by late winter in March, can use more fat to survive without significant winter feeding. Winter fasting by high-lipid herring may reflect a survival strategy; feeding may not be worth the associated predation risk if prey scarcity largely precludes growth and the risk of lipid depletion is low. Winter feeding triggered by lipid depletion is also seen in YOY striped bass Morone saxatilis (Hurst \& Conover 2001), indicating the tradeoff in winter predation and starvation risk occurs among diverse species. Food deprivation in herring (Robinson \& Pitcher 1989) and other schooling fishes (Morgan 1988, Sogard \& Olla 1997) decreases anti-predator schooling behavior. Predation risk would also be heightened during winter, when the low prey availability (Foy \& Paul 1999) requires greater foraging effort. The need to forage would be highest for small herring with low lipid stores that are unlikely to sustain them until food availability increases in spring (Paul \& Paul 1998). Additionally, their higher mass-specific metabolic rates (Schultz \& Conover 1999) would cause them to exhaust lipid stores more quickly than larger herring. Risk appears lowest for large fish that store the most lipid prior to winter, not only because they would be better at escaping predation attempts, but also because they could endure longer without foraging and increasing exposure to predators.

Energy-dependent mortality risk is not necessarily equivalent to size-dependent risk, as feeding triggered by low stored energy levels was not limited to smaller fish. While lipid generally increased with size, herring of a given size showed a wide range of lipid levels that could reflect differences in their prior feeding or thermal histories. Regardless of the cause, observations of lipid levels and stomach fullness indicate many large fish deplete their lipid stores by March and must also forage. Although many herring in March exceeded the modal size of YOY herring consumed by groundfish, they were within the range of sizes eaten, thus increased foraging activity could still increase predation risk for larger herring with low energy stores. Consequently, juvenile herring survival may depend on total energy, the product of body mass and energy density, similarly to YOY pollock (Heintz et al. 2013). Winter survival is likely highest among fish larger than the critical size for fat storage in November, due to their reduced risk of both starvation and foraging-induced predation.

Relatively little work has been published about sizedependent winter mortality in Pacific herring. Sizedependent mortality is often inferred from increases in mean size in a population over winter, but evidence distinguishing this effect from growth is limited. Juvenile herring in Resurrection Bay, Alaska and PWS show an increase in average length over winter, which likely reflects loss of smaller herring from the population because the low mean stored energy makes growth unlikely (Paul \& Paul 1998, Foy \& Paul 1999). Though the present study lacks unbiased mean size estimates, the small herring present in November collections were less common during March. Small herring in this study in November and March allocated available energy to growth rather than fat, but significant winter growth was unlikely because RNA/ DNA levels were much lower than in earlier autumn (September 2012 mean RNA/DNA $15.1 \pm 0.2$; Heintz et al. 2017) and ap-proached minimum levels needed for routine metabolism. Building on past efforts, we thus present further evidence that size-dependent winter mortality of YOY is an important factor in northern Pacific Herring populations.

\subsection{Environmental influences on survival}

Cool autumn temperatures may promote better pre-winter herring condition, at least over the temperature range and feeding conditions present in this study. One of the important features of this study is that sample collections spanned years before and during the North Pacific Ocean marine heat wave event of 2014-2015 ('The Blob'; Bond 2014, Di Lorenzo \& 
Mantua 2016). This enabled comparisons of herring across a relatively large change in annual average sea temperatures. Over the 7-yr study period, herring had the best condition in 2012, when November water temperature was coldest. Cold temperature may promote higher lipid levels in herring by slowing metabolism and rate of fat loss. Higher fat reserves would not only minimize imminent starvation risk, but also delay the need for foraging activity with its attendant predation risk. Herring were the leanest in 2015, the warmest year of the study. An increase in autumn and winter temperatures of $2^{\circ} \mathrm{C}$ from 1996 to 1997 was associated with lower zooplankton abundance in PWS (Foy \& Norcross 2001). Warm years may thus decrease autumn zooplankton abundance, resulting in poor feeding and low fat stores before winter, both of which were observed in 2015. Even with abundant food, fat storage capacity can decline when temperatures increase beyond a species-dependent optimum (Copeman et al. 2017). Regardless of the mechanism, the contrast in lipid levels we observed matched the pattern in herring energy density between the warm year 2015 and the cold year 2012 (Gorman et al. 2018).

The finding of high RNA/DNA in the coldest year suggests better growth at lower temperatures, at least over the temperature range observed in this study. However, it is unclear to what extent high RNA/DNA in a colder year is due to lower efficiency of translating RNA into protein at colder temperatures. While elevated RNA/DNA indicates growth in mass and length in larval and juvenile fish (Bulow 1970, Folkvord et al. 1996), the amount of growth represented by a given level of RNA is temperaturesensitive. A temperature increase of $1^{\circ} \mathrm{C}$ can increase growth $1 \%$ per day at a given RNA/DNA level for some marine fish larvae, though RNA/DNA ratios are generally comparable without corrections for temperatures within $2^{\circ} \mathrm{C}$ (Buckley et al. 1999). For our direct RNA/DNA comparisons among bays, the temperature differences among bays were typically small $\left(<2^{\circ} \mathrm{C}_{\text {; }}\right.$ R. Campbell, Prince William Sound Science Center, pers. comm.). In contrast, lower growth efficiency at colder temperatures likely contributed to the higher RNA/DNA seen in March than November, which typically differed by more than $3^{\circ} \mathrm{C}$. Likewise, higher RNA/DNA may be required by YOY herring in a colder year to achieve similar growth as lower RNA/DNA in a warmer year. High temperature may promote growth when food is abundant, but may not if food is limited or temperatures exceed the optimal range for PWS herring. The positive temperaturegrowth relationship for PWS herring can break down in years when the July-August average temperature exceeds $12.5^{\circ} \mathrm{C}$ (Batten et al. 2016). August temperatures approached that point in 2014-2015, years marked by persistent unusually warm sea temperatures ('The Blob') in the North Pacific Ocean (Bond 2014, Di Lorenzo \& Mantua 2016). More observations, particularly in cold years, would help clarify the response of herring RNA/DNA and growth to temperature. Given recent findings that warm summers and abundant plankton promote first-year herring growth (Batten et al. 2016), and the present finding that herring condition before and after winter was best in a cold year, the best temperature conditions supporting YOY herring survival are likely a warm summer followed by a cold winter. Concurrently, zooplankton prey quantity and quality must be sufficient to promote high growth in summer and forestall starvation in winter.

The effect of diet differences on YOY herring growth and condition was less clear than the effect of temperature, though euphausiids may have played an important role. Herring prey consumption appeared highest during November of 2011 among the 5 years analyzed, but did not lead to greater growth or fat stores relative to other years. Euphausiid consumption by large herring, consistent with previous observations (Foy \& Norcross 1999), is presumably enabled by large gape size and swimming ability and further reinforces the survival advantages of large size. Though the effect was weak, large herring with euphausiiddominated diets had higher growth and possibly greater fat stores than similarly sized herring eating other prey, suggesting a positive feedback loop between herring size and euphausiid consumption. Differences in euphausiid consumption among bays in 2011, when feeding conditions were best, may have contributed to differences in herring condition. Herring growth and lipid levels in 2011 were highest in Whale Bay, where diets were euphausiid-dominated. Availability of euphausiids, with their large size and high energy density relative to copepods and other zooplankton (Foy \& Norcross 1999), could maximize return on herring foraging effort. Given that euphausiids may also reduce predation pressure on herring by serving as alternative prey for groundfish and whales (Lang et al. 2005, Schweigert et al. 2010), euphausiids may promote herring survival in years when they are abundant, though not all bays may support euphausiids and benefit herring equally.

Different oceanographic conditions among bays may drive spatial differences in herring condition observed in our study and previous studies (Norcross et al. 2001). For example, the tendency for higher 
herring growth and energy stores observed in Whale Bay, a deep unsilled fjord, were likely driven by a unique combination of local zooplankton production and seasonal influx of zooplankton from the Gulf of Alaska (Gay \& Vaughan 2001, Gorman et al. 2018). This localized variability in winter habitat quality means that bays likely contribute unequally to recruitment to the PWS herring stock, though no single bay is consistently best at promoting juvenile herring survival. Overwintering in several diverse bays may thus represent a portfolio strategy (Figge 2004, Schindler et al. 2015) in which variation in overall PWS herring abundance is dampened by minimizing the impact of occasionally poor conditions and high mortality in any given bay.

Given the importance of first winter survival in determining eventual recruitment to the adult stock (Hurst 2007, Norcross et al. 2001), our findings suggest biological and ecological variables that should be considered for development of winter survival models. The size-based trade-off in growth versus energy storage we observed at the start of winter, and an energy storage-based tradeoff in winter feeding versus not feeding, suggest that quantitative models of YOY herring winter survival should use unbiased estimates of late autumn size and energy distributions. In addition, challenges to herring winter survival should be characterized by seasonal temperature measurements and estimates of food consumption and local predator densities. While this study focused on the survival of herring during their first winter, mortality at other periods can strongly influence survival until recruitment to the adult stock. High first winter survival appeared to be promoted by good condition of YOY herring in 2012, as indicated by aerial survey observations of schools of age-1 herring an order of magnitude more abundant than usual in summer 2013 (Pegau 2014). The 2012 YOY herring were expected to contribute strongly to the 2015 adult spawning stock at age 3, but low spawner abundance in 2015 made the stock age composition unclear (S. Moffitt, Alaska Department of Fish and Game, pers. comm.). Regardless of the 2012 cohort strength relative to other years, low overall stock size in 2015 suggests high mortality after their first winter and before recruiting at age 3, possibly related to the extreme warming event in the North Pacific in 2014-2015. High water temperatures in that period are linked to a range of impacts in the North Pacific (Di Lorenzo \& Mantua 2016), including Gulf of Alaska fish species and their predators (Zador \& Yasumiishi 2017). Effects on fish included record low abundances of larval and age-1 juvenile walleye pollock (Zador \& Yasumiishi 2016, Dorn et al. 2017) and declines in abundance of juvenile Pacific cod across age classes (Barbeaux et al. 2017), likely due to increased natural mortality. High juvenile fish mortality was likely driven partly by food limitation, caused by shifts toward smaller, lower energy zooplankton prey during the warming event (McKinstry \& Campbell 2018, Batten et al. 2018). The unusual marine heatwave may thus have contributed to high mortality of age-1+ juvenile herring, including the 2012 cohort. In more typical years, a key determinant of recruitment is survival through the first winter, which we have shown can be promoted by large size and high fat stores in autumn.

Acknowledgements. We thank the Prince William Sound Science Center, Scott Pegau, Kristen Gorman, Mary Anne Bishop, Michele Buckhorn, Tom Kline, Julia McMahon, Megan Roberts, Jennifer Todd, Ryan Bare, Sarah Ballard, Robert Bradshaw, Sarah Christiansen, Eamon Conheady, Keith Cox, Andrew Eller, Emily Fergusson, Hannah Findlay, Corey Fugate, Meghan Garrison, Kevin Heffern, Lia Heifetz, Tayler Jarvis, Jacek Maselko, John Moran, Stella Mosher, Darcie Neff, Bonita Nelson, Tom Parker, Connor Pihl, Erik Pihl, Ann Robertson, Lawrence Schaufler, Ashwin Sreenivasan, Wes Strasburger, and Jared Weems for assistance with this project. We also thank Franz Mueter, Gordon Kruse, and Russ Hopcroft for reviewing drafts of this manuscript. This work was supported by the Exxon Valdez Oil Spill Trustee Council, Anchorage, AK (Projects 10100132-D, 12120111-M) and the National Marine Fisheries Service. The findings and conclusions presented in this paper are those of the authors and do not necessarily represent the views or position of the Trustee Council or the National Marine Fisheries Service. Reference to trade names does not imply endorsement by the National Marine Fisheries Service, NOAA.

\section{LITERATURE CITED}

Anderson JT (1988) A review of size dependent survival during pre-recruit stages of fishes in relation to recruitment. J Northwest Atl Fish Sci 8:55-66

Anderson MJ (2001) A new method for non-parametric multivariate analysis of variance. Austral Ecol 26:32-46

Barbeaux S, Aydin K, Fissel B, Holsman K and others (2017) Assessment of the Pacific cod stock in the Gulf of Alaska. Stock assessment and fishery evaluation report for the groundfish resources of the Gulf of Alaska. North Pacific Fishery Management Council, Anchorage, AK

Batten SD, Moffitt S, Pegau WS, Campbell R (2016) Plankton indices explain interannual variability in Prince William Sound herring first year growth. Fish Oceanogr 25: 420-432

*Batten SD, Raitsos DE, Danielson S, Hopcroft R, Coyle K, McQuatters-Gollop A (2018) Interannual variability in lower trophic levels on the Alaskan Shelf. Deep Sea Res II 147:58-68

*Beamish RJ, Mahnken C (2001) A critical size and period hypothesis to explain natural regulation of salmon abun- 
dance and the linkage to climate and climate change. Prog Oceanogr 49:423-437

Beauchamp DA, Cross AD, Armstrong JL, Myers KW, Moss JH, Boldt JL, Haldorson LJ (2007) Bioenergetic responses by Pacific salmon to climate and ecosystem variation. $\mathrm{N}$ Pac Anadromous Fish Comm Bull 4:257-269

Bishop MA, Powers SP (2013) Top-down regulation by predatory fish on juvenile herring in Prince William Sound. Exxon Valdez Oil Spill Restoration Project Final Report. Project no. 10100132-G. Prince William Sound Science Center, Cordova, AK

Bishop MA, Gray B, Pegau S (2017) Fish predation on juvenile herring in Prince William Sound, Alaska, 2009-2012, EVOS Prince William Sound Herring Program [Data set]. Axiom Data Science. https://doi.org/10.24431/rw1k1z (accessed 10 Aug 2018)

Bond N (2014) The blob: warm water off the coast of the PNW and what it may mean for our summer weather. Off Wa State Climatol Newsl 8:2-4

Buckley LJ (1984) RNA-DNA ratio: an index of larval fish growth in the sea. Mar Biol 80:291-298

* Buckley L, Caldarone E, Ong TL (1999) RNA-DNA ratio and other nucleic acid-based indicators for growth and condition of marine fishes. Hydrobiologia 401:265-277

Bulow FJ (1970) RNA-DNA ratios as indicators of recent growth rates of a fish. J Fish Res Board Can 27:2343-2349

* Burnham KP, Anderson DR (2004) Multimodel inference understanding AIC and BIC in model selection. Sociol Methods Res 33:261-304

Caldarone EM, Wagner M, St. Onge-Burns J, Buckley LJ (2001) Protocol and guide for estimating nucleic acids in larval fish using a fluoresence microplate reader. Northeast Fish Sci Cent Ref Doc 01-11. National Marine Fisheries Service, Woods Hole, MA

Caldarone EM, Clemmesen CM, Berdalet E, Miller TJ and others (2006) Intercalibration of four spectrofluorometric protocols for measuring RNA/DNA ratios in larval and juvenile fish. Limnol Oceanogr Methods 4:153-163

Christensen B (1996) Predator foraging capabilities and prey antipredator behaviours: pre- versus postcapture constraints on size-dependent predator-prey interactions. Oikos 76:368-380

Copeman LA, Laurel BJ, Spencer M, Sremba A (2017) Temperature impacts on lipid allocation among juvenile gadid species at the Pacific Arctic-Boreal interface: an experimental laboratory approach. Mar Ecol Prog Ser 566:183-198

Coyle KO, Paul AJ, Ziemann DA (1990) Copepod populations during the spring bloom in an alaskan subarctic embayment. J Plankton Res 12:759-797

Day RW, Quinn GP (1989) Comparisons of treatments after an analysis of variance in ecology. Ecol Monogr 59:433-463

Di Lorenzo E, Mantua N (2016) Multi-year persistence of the 2014/15 North Pacific marine heatwave. Nat Clim Chang 6:1042-1047

Dorn M, Aydin K, Fissel B, Jones D, McCarthy A, Palsson W, Spalinger K (2017) Assessment of the walleye pollock stock in the Gulf of Alaska. Stock assessment and fishery evaluation report for the groundfish resources of the Gulf of Alaska. North Pacific Fishery Management Council, Anchorage, AK, p 47-182

Farley EV, Starovoytov A, Naydenko S, Heintz R and others (2011) Implications of a warming eastern Bering Sea for Bristol Bay sockeye salmon. ICES J Mar Sci 68: 1138-1146
Figge F (2004) Bio-folio: applying portfolio theory to biodiversity. Biodivers Conserv 13:827-849

Folch J, Lees M, Sloane Stanley GH (1957) A simple method for the isolation and purification of total lipids from animal tissues. J Biol Chem 226:497-509

Folkvord A, Ystanes L, Johannessen A, Moksness E (1996) RNA: DNA ratios and growth of herring (Clupea harengus) larvae reared in mesocosms. Mar Biol 126:591-602

*Foy RJ, Norcross BL (1999) Spatial and temporal variability in the diet of juvenile Pacific herring (Clupea pallasii) in Prince William Sound, Alaska. Can J Zool 77 : 697-706

Foy RJ, Norcross BL (2001) Temperature effects on zooplankton assemblages and juvenile herring feeding in Prince William Sound, Alaska. In: Funk F, Blackburn J, Hay D, Paul AJ, Stephenson R, Toresen R, Witherell D (eds) Herring: expectations for a new millennium. Proc $18^{\text {th }}$ Lowell Wakefield Fish Symp. Alaska Sea Grant College Program, Fairbanks, AK, p 21-35

F Foy RJ, Paul AJ (1999) Winter feeding and changes in somatic energy content of age-0 Pacific herring in Prince William Sound, Alaska. Trans Am Fish Soc 128:1193-1200

Games PA, Howell JF (1976) Pairwise multiple comparison procedures with unequal n's and/or variances: a Monte Carlo study. J Educ Stat 1:113-125

Gay SM, Vaughan SL (2001) Seasonal hydrography and tidal currents of bays and fjords in Prince William Sound, Alaska. Fish Oceanogr 10:159-193

* Gorman KB, Kline TC Jr, Roberts ME, Sewall FF, Heintz RA, Pegau WS (2018) Spatial and temporal variation in winter condition of juvenile Pacific herring (Clupea pallasii) in Prince William Sound, Alaska: oceanographic exchange with the Gulf of Alaska. Deep Sea Res II 147: 116-126

*Heintz RA, Vollenweider JJ (2010) Influence of size on the sources of energy consumed by overwintering walleye pollock (Theragra chalcogramma). J Exp Mar Biol Ecol 393:43-50

*Heintz RA, Siddon EC, Farley EJ, Napp JM (2013) Correlation between recruitment and fall condition of age-0 pollock (Theragra chalcogramma) from the eastern Bering Sea under varying climate conditions. Deep Sea Res II 94:150-156

Heintz R, Sewall F, Gorman K, Pegau S (2017) High temporal and spatial resolution study of herring condition in Prince William Sound, growth and diet data, 2011-2012: EVOS Herring Program [Data set]. Axiom Data Science. https://doi.org/10.24431/rw1k16 (accessed 10 Aug, 2018)

*Hulson PJ, Miller SE, Quinn TJ, Marty GD, Moffitt SD, Funk F (2008) Data conflicts in fishery models: incorporating hydroacoustic data into the Prince William Sound Pacific herring assessment model. ICES J Mar Sci 65:25-43

* Hurst TP (2007) Causes and consequences of winter mortality in fishes. J Fish Biol 71:315-345

Hurst TP, Conover DO (2001) Diet and consumption rates of overwintering YOY striped bass, Morone saxatilis, in the Hudson River. Fish Bull 99:545-554

*Huss M, Bystrom P, Strand A, Eriksson LO, Persson L (2008) Influence of growth history on the accumulation of energy reserves and winter mortality in young fish. Can J Fish Aquat Sci 65:2149-2156

Iverson SJ, Frost KJ, Lowry LF (1997) Fatty acid signatures reveal fine scale structure of foraging distribution of harbor seals and their prey in Prince William Sound, Alaska. Mar Ecol Prog Ser 151:255-271 
Kloke JD, McKean JW (2012) Rfit: Rank-based estimation for linear models. R J 4:57-64

Kloke J, McKean J (2016) Rfit: Rank-based estimates and inference for linear models. R package. https://CRAN. r-project.org/package $=$ Rfit

Lang GM, Livingston PA, Dodd KA (2005) Groundfish food habits and predation on commercially important prey species in the eastern Bering Sea from 1997 through 2001. NOAA Tech Memo NMFS-AFSC-158. US Dept of Commerce

Laurel BJ, Spencer M, Iseri P, Copeman LA (2016) Temperature-dependent growth and behavior of juvenile Arctic cod (Boreogadus saida) and co-occurring North Pacific gadids. Polar Biol 39:1127-1135

McKinstry CA, Campbell RW (2018) Seasonal variation of zooplankton abundance and community structure in Prince William Sound, Alaska, 2009-2016. Deep Sea Res II 147:69-78

*Miller TJ, Crowder LB, Rice JA, Marschall EA (1988) Larval size and recruitment mechanisms in fishes: toward a conceptual framework. Can J Fish Aquat Sci 45:1657-1670

*Morgan MJ (1988) The effect of hunger, shoal size and the presence of a predator on shoal cohesiveness in bluntnose minnows, Pimephales notatus Rafinesque. J Fish Biol 32:963-971

Moss JH, Beauchamp DA, Cross AD, Myers KW, Farley EJ, Murphy JM, Helle JD (2005) Evidence for size-selective mortality after the first summer of ocean growth by pink salmon. Trans Am Fish Soc 134:1313-1322

Muggeo VM (2003) Estimating regression models with unknown break-points. Stat Med 22:3055-3071

*Muggeo V (2014) Segmented. R package. https:// CRAN. r-project.org/package=segmented

Norcross BL, Brown ED (2001) Estimation of first-year survival of Pacific herring from a review of recent stagespecific studies. In: Funk F, Blackburn J, Hay D, Paul AJ, Stephenson R, Toresen R, Witherell D (eds) Herring: expectations for a new millennium. Proc $18^{\text {th }}$ Lowell Wakefield Fish Symp. Alaska Sea Grant College Program, Fairbanks, AK, p 535-558

Norcross BL, Brown ED, Frandsen M, Gay SM and others (2001) A synthesis of the life history and ecology of juvenie Pacific herring in Prince William Sound, Alaska. Fish Oceanogr 10:42-57

Oksanen J, Guillaume B, Friendly M, Kindt R and others (2018) Vegan. R package. https://CRAN.r-project.org/ package=vegan

Patrick V (2000) Evolution equation models for the advective transport during spring and the fasting physiology during winter of age-0 Pacific herring in Prince William Sound, Alaska. ISR Tech Rep 2000-12. Institute for Systems Research, University of Maryland, College Park, MD

Paul AJ, Paul JM (1998) Comparisons of whole body energy content of captive fasting age zero Alaskan Pacific herring (Clupea pallasi Valenciennes) and cohorts over-wintering in nature. J Exp Mar Biol Ecol 226:75-86

Pegau WS (2014) Pacific herring in Prince William Sound: a synthesis of recent findings. Exxon Valdez Long-Term Herring Research and Monitoring Program Report (Restoration Project 14120111). Prince William Sound Science Center, Cordova, AK

Post JR, Parkinson EA (2001) Energy allocation strategy in young fish: allometry and survival. Ecology 82:1040-1051

Robinson CJ, Pitcher TJ (1989) The influence of hunger and ration level on shoal density, polarization and swimming speed of herring, Clupea harengus L. J Fish Biol 34: 631-633

Scharf FS, Juanes F, Rountree RA (2000) Predator sizeprey size relationships of marine fish predators: interspecific variation and effects of ontogeny and body size on trophic-niche breadth. Mar Ecol Prog Ser 208: 229-248

Scheuerell MD, Schindler DE (2003) Diel vertical migration by juvenile sockeye salmon: empirical evidence for the antipredation window. Ecology 84:1713-1720

Schindler DE, Armstrong JB, Reed TE (2015) The portfolio concept in ecology and evolution. Front Ecol Environ 13: 257-263

* Schultz ET, Conover DO (1999) The allometry of energy reserve depletion: test of a mechanism for size-dependent winter mortality. Oecologia 119:474-483

* Schweigert JF, Boldt JL, Flostrand L, Cleary JS (2010) A review of factors limiting recovery of Pacific herring stocks in Canada. ICES J Mar Sci 67:1903-1913

Sogard SM (1997) Size-selective mortality in the juvenile stage of teleost fishes: a review. Bull Mar Sci 60:1129-1157

Kogard SM, Olla BM (1996) Food deprivation affects vertical distribution and activity of a marine fish in a thermal gradient: potential energy-conserving mechanisms. Mar Ecol Prog Ser 133:43-55

Sogard SM, Olla BL (1997) The influence of hunger and predation risk on group cohesion in a pelagic fish, walleye pollock Theragra chalcogramma. Environ Biol Fishes 50: 405-413

Sogard SM, Olla BL (2000) Endurance of simulated winter conditions by age- 0 walleye pollock: effects of body size, water temperature and energy stores. J Fish Biol 56:1-21

Sreenivasan A (2011) Nucleic acid rations as an index of growth and nutritional ecology in Pacific cod (Gadus macrocephalus), walleye pollock (Theragra chalcogramma), and Pacific herring (Clupea pallasii). PhD dissertation, University of Alaska, Fairbanks, AK

Stallings CD, Coleman FC, Koenig CC, Markiewica DA (2010) Energy allocation in juveniles of a warm-temperate reef fish. Environ Biol Fishes 88:389-398

* Stokesbury KDE, Kirsch J, Patrick EV, Norcross BL (2002) Natural mortality estimates of juvenile Pacific herring (Clupea pallasi) in Prince William Sound, Alaska. Can J Fish Aquat Sci 59:416-423

* Thomas GL, Thorne RE (2001) Night-time predation by Steller sea lions. Nature 411:1013

*Thomas GL, Thorne RE (2003) Acoustical-optical assessment of Pacific herring and their predator assemblage in Prince William Sound, Alaska. Aquat Living Resour 16: 247-253

Vollenweider JJ, Heintz RA, Hershberger PK, Gregg JL, Sreenivasan A, Cox K (2011a) Are herring (Clupea pallasii) energetics in Prince William Sound a limiting factor in successful recruitment of juveniles or reproduction investment of adults? Exxon Valdez Oil Spill Restoration Project Final Report (Restoration Project: 100806), National Marine Fisheries Service, Juneau, AK

Vollenweider JJ, Heintz RA, Schaufler L, Bradshaw R (2011b) Seasonal cycles in whole-body proximate composition and energy content of forage fish vary with water depth. Mar Biol 158:413-427

Welch BL (1951) On the comparison of several mean values: an alternative approach. Biometrika 38:330-336

Wood SN (2006) Generalized additive models: an intro- 
duction with R. Chapman \& Hall / CRC, London

Zador S, Yasumiishi E (2016) Ecosystem Considerations 2016: Status of the Gulf of Alaska marine ecosystem. Stock assessment and fishery evaluation report for the groundfish resources of the Gulf of Alaska. North Pacific Fishery Management Council, Anchorage, AK

Zador S, Yasumiishi E (2017) Ecosystem Considerations 2017 :

Editorial responsibility: Stylianos Somarakis,

Heraklion, Greece
Status of the Gulf of Alaska marine ecosystem. Stock assessment and fishery evaluation report for the groundfish resources of the Gulf of Alaska. North Pacific Fishery Management Council, Anchorage, AK

K Zheng J (1996) Herring stock-recruitment relationships and recruitment patterns in the North Atlantic and Northeast Pacific oceans. Fish Res 26:257-277

Submitted: October 17, 2018; Accepted: May 29, 2019

Proofs received from author(s): July 23, 2019 